\title{
ギャンブル場面における大損失への対応と性格特性 (2)
}

\author{
$\bigcirc$ 高橋伸彰 $^{1} \cdot$ 高野裕治 $^{1} \cdot$ 田中大介 ${ }^{2} \cdot$ 廣中直行 $^{1}$ (非会員) \\ ( ${ }^{1}$ 科学技術振興機構, ERATO, 下條潜在脳機能プロジェクト・2 科学技術振興機構, 社会技術研究開発センター) \\ キーワード: ギャンブル・意志決定・性格特性
}

\author{
The reaction for big loss at gamble situation and personality trait (2) \\ Nobuaki TAKAHASHI ${ }^{1}$, Yuji TAKANO ${ }^{1}$, Daisuke TANAKA ${ }^{2}$, and Naoyuki HIRONAKA ${ }^{1, \#}$ \\ $\left({ }^{1}\right.$ SHIMOJO Implicit Brain Function Project, ERATO, JST, ${ }^{2}$ RISTEX, JST) \\ Key words: gamble, decision making, personality
}

\section{目 的}

我々はこれまでに, ギャンブルにのめり込んでいくプロセ スのモデルとして，ギャンブル課題 (Iowa Gambling Task; Bechara, et al., 2000) における大損失カードを含むデッキへ の選好が深まる過程について検討してきた (高野ら，2008)。 ギャンブル課題とは，4 つのカードデッキを各試行において 選択させ，その直後にある額の金銭が得られるが，その金銭 を得た後，手持ちの金銭を徵収されることもあるし，金銭を 徵収されない場合もあるようなギャンブル状況を模した課題 である。これら 4 つのデッキのうち，2 つのデッキが不利な デッキとなっている。また, これらのデッキはそれぞれ, 徵 収される頻度が増加するか, 額が増加するように特徵づけら れている。高野ら (2008) は前者の徴収される頻度が増加す るデッキ (デッキ1) に対する選択は試行が進むにつれて選 択数が減少していくのに対して, 後者の額が増加するデッキ (デッキ 2) については減少傾向が認められず，被験者間でば らつきが生じることから，デッキ 2 に対する選好に着目し， このデッキに選好を示す者は衝動性・熟慮性の検査として知 られる Matching Familiar Figure Test (MFFT) の誤答数が多い ことを報告した。本研究では, 額が増加し大負けを引き起こ すデッキに対して選好する群と回避する群とに分け，これら の群で性格特性に差が認められるか否か検討した。

\section{実 験 1}

方法

被験者 大学生 57 名 (男性 23 名, 女性 34 名)。

手続き パーソナルコンピュータを用いて, ギャンブル課題 日本語版を実施した。画面には 4 つのカードデッキが表示さ れ，被験者はマウスクリックにて各デッキを選択するように 教示された。獲得額, 損失額, および現在の所持金について は画面上部にて表示された。デッキ 2 には 10 万円以上没収さ れる大損失カードが 6 枚含まれており，この大損失カードの 選択数が 2 以下の者を回避群 (23 名), 4 以上の者を選好群 $(20$ 名）として群分けを行った (本題 (1) 参照)。性格検査として, 時間的展望体験尺度, 特性不安尺度, 刺激希求性尺度, 認知 的熟慮性-衝動性尺度を用いた。

\section{結果}

選好群は回避群と比較して, 熟慮性が有意に高く $(\mathrm{t}(41)=$ $-2.08, \mathrm{p}<.05)$, 特性不安が低い傾向にあった ( $\mathrm{t}(41)=2.00, \mathrm{p}$ $<.10)$ 。時間的展望体験尺度と刺激希求性については有意な差 が認められなかった (Figure 1)。

\section{実 験 2}

方法

被験者 大学生 38 名 (男性 21 名, 女性 17 名)。

手続き 実験 1 と同様の手続きにてギャンブル課題を実施し, 群分けを行った (回避群 9 名, 選好群 11 名)。性格検査とし
ては NEO-PI-Rを施行した。

\section{結果}

選好群は回避群と比較して, 空想および審美性が低く (空 想, $\mathrm{t}(18)=2.50, \mathrm{p}<.05$; 審美性, $\mathrm{t}(18)=2.60, \mathrm{p}<.05)$, 慎重 である $(\mathrm{t}(18)=-2.42, \mathrm{p}<.05)$ と自己を認識していた (Figure 2)。

\section{考 察}

実験 1 では自身を熟慮的であると認識している者の方がよ りデッキ 2 を選好し, 実験 2 では慎重であると認識している 者の方がよりデッキ2 を選好していた。このことは熟慮的で あり慎重な者ほど結果的に不利となるような選択行動をとっ てしまうことを示唆している。デッキ 2 は確かに大損失を生 じさせるカードが含まれているが，ハイリスク・ハイリター ンのデッキとなっている。よって，この結果は，より自身を 熟慮的であり慎重であると考えている者の方が，デッキ 2 に より生じた大損失をデッキ 2 によって取り返そうと考える傾 向にあることを示唆している。このように, デッキ 2 への選 好が深まる過程は，合理的に判断をしようとして，かえって リスクの高い行動をとってしまい, 結果としてギャンブルに はまり込んでいってしまう人のモデルとして考えられる。こ の研究を発展させていくことによって, ギャンブルにはまり 込んでいく人たちの理解と支援につながることが見込まれる。
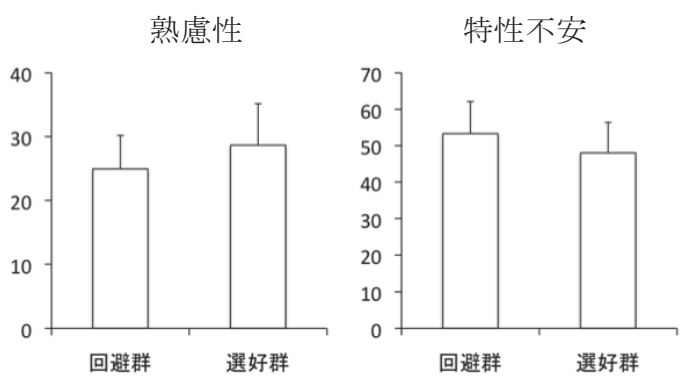

Figure 1. 選好群・回避群毎の熟慮性得点および特性不安得点
空想

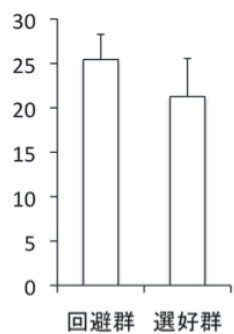

審美性

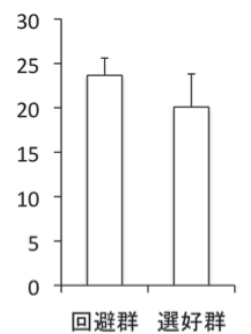

慎重さ

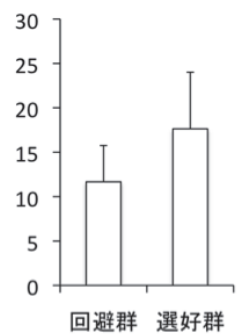

Figure 2. 選好群 - 回避群毎の NEO-PI-R 得点 